\title{
Surfaces
}

\section{CAUGHT IN THE NET. NOTES FROM THE ELECTRONIC UNDERGROUND}

\section{Bill Readings}

Volume 4, 1994

SUR LA PUBLICATION ÉLECTRONIQUE

ON ELECTRONIC PUBLICATION

URI : https://id.erudit.org/iderudit/1064957ar

DOI : https://doi.org/10.7202/1064957ar

Aller au sommaire du numéro

Éditeur(s)

Les Presses de l’Université de Montréal

ISSN

1188-2492 (imprimé)

1200-5320 (numérique)

Découvrir la revue

Citer cet article

Readings, B. (1994). CAUGHT IN THE NET. NOTES FROM THE ELECTRONIC

UNDERGROUND. Surfaces, 4. https://doi.org/10.7202/1064957ar
Résumé de l'article

Réflexion sur les changements épistémologiques et institutionels qu'entraîne l'adoption des nouvelles technologies électroniques par la recherche et la publication savantes. L'aueur s'interroge spécifiquement sur les effets critiques de ces transformations récentes sur les modes de légitimation du savoir et sur les pratiques académiques.
Copyright (C) Bill Readings, 1994

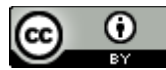

Ce document est protégé par la loi sur le droit d'auteur. L'utilisation des services d'Érudit (y compris la reproduction) est assujettie à sa politique d'utilisation que vous pouvez consulter en ligne.

https://apropos.erudit.org/fr/usagers/politique-dutilisation/ 
CAUGHT IN THE NET

NOTES FROM THE ELECTRONIC UNDERGROUND

Bill Readings

\begin{abstract}
Reflections on the epistemological and institutional shifts in scholarly research and publication that are brought about by electronic technology. Particular attention is paid to the potential crisis in current modes of the legitimation of knowledge and scholarly practices.
\end{abstract}

\title{
RÉSUMÉ
}

Réflexion sur les changements épistémologiques et institutionels qu'entraîne l'adoption des nouvelles technologies électroniques par la recherche et la publication savantes. L'aueur s'interroge spécifiquement sur les effets critiques de ces transformations récentes sur les modes de légitimation du savoir et sur les pratiques académiques.

At the 1993 MLA convention in Toronto, the American dialect society named "information super highway" as the word of 1993. Once we've finished pointing out that this is not one word but three, and lamenting the failure of 
its rival "Bobbitize" (a testimony to the fact that even the members of the MLA are not free from castration anxiety), it may be worth asking what the implications of this designation may be for the scholarly community. For academics too are drivers on the highway. While they may have been lambasted by Stanley Fish for their tendency to prefer Volvos to sportier models, the time is not far off when electronic publishing can provide academics with the Mercedes Benz communicational vehicle for which Anne Okerson recently appealed.[1]

The massive growth in electronic journals over the last couple of years continues exponentially. Framed by the rising costs of traditional scholarly publishing and the increasing restrictions on library budgets, the turn to electronic publishing seems to be the way of the future. Certainly, such was the conclusion of a recent article in the December 15 edition of The Chronicle of Higher Education. As is customary in such reflections, The Chronicle assesses the impact of computer communications technology upon scholarly publishing in "prosthetic" terms. By this I mean that the new technology is understood to offer a way of extending or improving existing practices. The costs and delays of production and distribution are massively reduced: there are minimal staffing costs, no printing or distribution costs, and no limitations of space. The electronic journal offers better value in terms of the quantity of information produced, the speed of its production, and the geo- graphical range of its distribution. Value for money: Attention K-Mart shoppers!

Some problems still remain, both financial and technical. On the financial side, the massively reduced production costs cannot be recouped from readers in the form of subscriptions, since the Internet is (amazingly enough) not a profit-making medium. Materials published on the Internet are free to subscribers. Hence the costs must be borne by producers, which requires advance funding from Universities and other agencies. The scenario is of course familiar from the debates over national health care: a generally subsidized service costs less overall and distributes its benefits more democratically according to need than does a service paid for by individual users. Given this, it is perhaps surprising that the Republicans didn't ban the Internet, with its spectre of "socialized communication" (and yes, you do sometimes have to queue to get on line). The fact is, of course, that all scholarly journals are subsidized to a greater or lesser degree, not least by research libraries, who represent a captive market that has made the acquistion of journals more and more attractive to for-profit publishers, which may be related to the fact that subscription costs rose $70 \%$ in the period from 1985-1992. Or perhaps I am too cynical about the desire of publishing houses to add their mite to the sum of human knowledge.

As for the technical problems, nearly all journals currently in existence produce their articles in the ASCII text format, which allows them to be mailed out to subscribers, using a LISTSERV mailer. However, ASCII text is ugly, and essays arrive looking like draft typescript. Furthermore, in a 
tribute to U.S. imperialism, the ASCII character set does not permit the use of accents or other diacritical marks. Those of us familiar with computer programmers may not be surprised that they apparently overlooked the existence of other languages than English while planning the system of communications for the 21st Century -- computer jockeys probably believe that the only important language apart from English is Klingon, and their anglocentrism is probably the product of too many Star Trek reruns rather than a conscious drive to global imperialism.[2]

As the editor of an electronic journal produced at a francophone university, which publishes in several European languages, I have been made particularly aware of this problem.[3] Around half our articles are in French, and whatever one may have thought in high school, those funny little accents are not simply a fiendish plot to make learning the language more difficult and to lower grades on written exams -- they really do make a difference. The journal, Surfaces, was conceived to address the problem of electronic publication in French and works by an FTP transfer. This means that files are bundled up or compressed and then decoded or unwrapped by the reader prior to printing. They are, as it were, slipped into an ASCII set envelope so that they can pass through the system. However, once the letter has arrived at its destination, it can be opened to reveal a fully formatted essay on Lacanian psychoanalysis, complete with diacritical marks, footnotes, and puzzling diagrams. The result looks exactly like an offprint from a learned journal, right down to the journal logo that ensures academic respectability. The Lord has finally provided that Mercedes Benz.

The only problem is that you have to come and pick it up. Readers browse through a list of published articles, mail them (in either Macintosh or MSDOS compressed formats) to their mainframe accounts, then download them to their terminals, decode, and print them. GOPHER already renders this process even simpler; MOSAIC will render it more pleasing to the eye.

The advantages of this procedure are manifold. Above all, the printed endproduct (paper is still easier to read and annotate) looks like a "real" journal article. I put the word "real" in quotation marks not merely because I've been reading too much Derrida. For the impact of such technology upon the academic community may not prove simply prosthetic. It may undermine, or at least restructure our understanding of the nature of academic publication, of what counts as a real scholarly article.

This possibility has to do with the legitimation function of scholarly publication, and the crisis that electronic publication is going to produce in the academic community's mode of legitimation. Walter Benjamin reminds us that the mode of reproduction does not simply affect the distribution of art works but also their nature; one might add that textual production cannot be understood aside from its mode of legitimation. Our usual sense 
that legitimation is something that happens to texts after they are produced is an illusion of modernity. The Eighteenth Century shift from rhetoric to aesthetics as the discourse governing textual production made writing into a creative practice rather than a "rule bound" one. Texts are thrown out into the world to be read, to sink or swim rather than being constructed according to the rules of poetics. This gives rise to an understanding of art as a process of innovation and experiment rather than the observance of strict genres; we get Wordsworth, Joyce, and Stein rather than Boileau.

Thus, literary criticism emerges as the location where legitimacy is discussed, where it is decided whether texts sink or swim. Hence, the mode of legitimation affects the nature of the texts produced, in this case, placing greater value upon experimentation than on strict adherence to classical rule. In modernity, a text becomes a classic only after it is written, through a process of critical judgment. The same goes for scholarly articles and the reputations that are built on them (and the salaries obtained in light of such reputations).

Because electronic publishing is likely to radically alter the nature of such critical discussions, we should recognize that it promises a quantum shift in the mode of legitimation and hence also in the production and circulation of texts. Things may never be the same again.

But at present, scholarly publishing has a function determined by the limits of the academic community. Articles are published and contribute to the sum of human wisdom, and they also obtain symbolic capital for their authors based on the place and frequency of their production. Up to now, electronic journals have not posed much of a threat to traditional hierarchies, as I became aware when recently evaluating a promotion dossier that included an article published in an electronic journal: the ASCII format was hardly likely to lend the piece the same air of authority as a traditional offprint. It occurred to me that a text from Surfaces would have looked much more impressive in this context. It then occurred to me that contemporary desktop publication software would have allowed the author to have simulated the effect of a regular journal offprint in the comfort of his/her own home, without enduring the messy business of submission and publication. Just fake it.

But, you will say, that would be cheating. Like lying about qualifications, it may work for a while, yet it will always be found out in the end. After all, real publications are indexed by the MLA.

What I had stumbled on, however, was a peripheral sympom of the legitimation crisis that the advent of electronic publication threatens to 
introduce into existing modes of evaluation and circulation of scholarly essays. First, let's take evaluation. Running an electronic journal introduces one to a particular set of problems. Normally, those who review essays for inclusion in scholarly journals know what they are supposed to do. Their function is to take exciting, innovative, and challenging work by younger scholars and find reasons to reject it. The same goes for book manuscripts: one receives a hundred dollars for rejecting a manuscript, but if you suggest that it should be published, the check never seems to arrive. However, in the electronic world, it is harder to find reasons to refuse publication. With no limits on space, one cannot recommend those sweeping cuts that will subsequently allow one to find the revised version insufficiently developed. The speed of publication means that a younger scholars can add the footnotes referring to that obscure but definitive essay by Professor Dryasdust and still get the essay published before they are refused tenure and driven out of the profession.

The obverse of this coin is the effect of electronic scholarly publishing on readers. More and more of us are becoming familiar with the Internet Syndrome, where one's colleague appears after an unexplained absence of several days, eyes glazed, hair unkempt, clutching an empty Pepsi can, and mumbling "I just logged on to check my E-mail, and then it was Thursday." The sheer quantity of information available on the Internet has reached the disproportion of the mathematical sublime: a glance at the available newsgroups makes the MLA convention program look like a model of classical restraint.

The vortex of information available confirms a more widespread contemporary cultural process: the decline of the general reader. There are no more general intellectuals, no more Lionel Trillings. The development of the university as a bureaucratic corporation for the handling of information means that no one person can survey an entire field, let alone knowledge as a whole. PMLA, for example, should serve to bring together the field of Literary and Linguistic studies that the MLA serves. It is reputed to refuse $93 \%$ of submissions. A selection process like that might be expected to ensure a certain vitality. But when was the last time you heard anyone say that they'd just seen a great "issue" of PMLA? Individual articles may seem important, yet nothing in our professional lives makes it necessary or worthwhile to read an entire issue. This is not to say that we are more stupid or more narrow minded now than we once were. My experience is that people read far more than they did thirty years ago. Specialization is a response to the swamping of the academic community with information, a process that electronic publication will intensify exponentially. We are moving towards an era of "narrow-casting", analogous to satellite television, in which the sheer range and availability of information exceeds the cognitive capacities of any individual. Fifty-seven journals and nothing on. 
The costs of electronic publication do not rise proportionally to the quantity of information published, and are not recouped proportionally to the number of readers attracted. The logic of electronic publishing is thus radically different from that of traditional journals; after all, if an essay might be of interest to ten people, why not publish it on the Internet? Academics are often accused of writing only for themselves, Internet renders this a possibility. Two challenges thus arise. First, we have to face more directly than ever before the question of the grounds upon which publication can be refused, since we can't appeal to physical constraints as an alibi. This will involve nothing less than the working out of a new set of criteria for the handling of scholarly research.

Already, book publication is replacing the journal article as the privileged mode of dissemination for scholarly information in literary studies in North America: more people will read (or at least buy) a \$15.00 paperback than will visit the library or take out a journal subscription. Indeed, it sometimes seems that journal articles exist solely to accumulate salary and tenure merit points, prior to their republication in expanded form. This is an interesting symptom: the preference in literary studies for the book over the journal article has grown in proportion to the disaggregation of the discipline. Hence in the hard sciences, or economics, where a common doxa exists, the journal article holds sway. But with the emergence of competing accounts of the legitimation of knowledge, competing versions of what counts as scholarly production (as is the case in literary studies), the book takes over from the journal. This is obviously because the publication side by side of works based on heterogeneous systems of legitimation becomes less and less attractive: readers want doxa, in general. One could also put this more positively, and say that once a discipline becomes a field of "real debate," then things tend to get too hot for the pages of a journal to hold.

Second, the question of what publication means is open. Electronic publication offers the following scenario. Librarians or libraries will cease to be warehouses of information and will become instead dealers in information, who locate, download, and print out articles on request. This is analogous to what seems to be happening in post-Fordist car production. As I understand it, car factories no longer produce cars en masse, so that dealers may then try to sell them. Rather, you go down to the dealer, pick out a model from among the samples on the floor, indicate your choice of color and accessories and it is then produced on demand and shipped. Nobody buys those cars on the floor; they're just samples, simulacra. Of course, I am exaggerating what is merely a tendency in the calibration of production to demand. What it means for scholarly production is that new modes in the evaluation of reception (and the consequent gaining of scholarly legitimacy) will arise. Electronic technology makes it possible to calculate with far greater accuracy and speed the number of times a given article is consulted. The spectre arises of the intellectual star of the 21st Century with a box in the corner of her or his computer screen counting the number of times their articles have been accessed today. Symbolic capital 
has never been so easy to calculate. Worried conversations will arise in the corridors of the MLA convention as older academics watch their reputations diminishing; more technically minded research assistants could be deputed to write software that would repeatedly access given articles in order to ensure that end of year bonus.

All of this means that we have to think very carefully about what the transition to electronic publishing implies for the scholarly community as a whole. We have to recognize that the university as an institution is becoming more and more corporate, that information is not primarily referential (information about something outside the university); instead, information is a unit of value within the system and serves to procure advancement within the university. In this context, the increased quantity, speed, and distribution that electronic publishing brings will not simply prosthetically improve existing practices; it promises to significantly alter the basis on which the system functions. The economic rationale is overwhelming: it remains to be seen whether academics will be capable of turning the shift to their advantage.

\section{Bill Readings \\ Comparative Literature Department readings@ere.umontreal.ca}

\section{Surface Page d'Accueil/Home Page}

[1]Ann Okerson, "Who's Writing? Online Journals on the Line: An Overview of Current Realities", paper presented at the MLA Convention, 1993, and published as Surfaces Vol. IV, \#102. This paper was presented on a panel organized by John Coldewey of the Council of Editors of Learned Journals. The participants were James O'Donnell, Ann Okerson, R.A. Shoaf, and myself -- the present essay is based on my remarks on this occasion.

[2]Evidence to the contrary is provided by the fact that the USA is the only country which requires no geographical suffix (such as .ca for Canada) for email: the US is situated as the center of the internet system.

[3]Surfaces was conceived by Wlad Godzich and Jean-Claude Guédon, both of the department of comparative literature at the Université de Montréal. For the three years of its existence, Jean-Claude Guédon has been responsible for the technical side of the journal, while I have edited the contents. The journal was made possible by a grant from the Québec Ministère de l'Enseignement supérieure et de la science (with the delightful acronym of MESS), release time and offices were provided by the Université de Montréal, and a grant of equipment from Apple Corporation. Now all we need is a government grant... 